\title{
High-dose chemotherapy with autologous hematopoietic stem cell transplantation in children with atypical teratoid/rhabdoid CNS tumors
}

\author{
Liudmila V. Olkhova ${ }^{1}$, Olga G. Zheludkova ${ }^{2}$, Ludmila S. Zubarovskaya ${ }^{3}$, Anna Yu. Smirnova ${ }^{4}$, Yulia V. Dinikina ${ }^{4,5}$, \\ Asmik G. Gevorgyan ${ }^{3}$, Andrey S. Levashov ${ }^{6}$, Elena V. Skorobogatova ${ }^{1}$ \\ ${ }^{1}$ Russian Pediatric Clinical Hospital, N. N. Pirogov Russian National Medical University, Moscow, Russia \\ ${ }^{2}$ St. Luke Clinical Research Center for Children, Moscow, Russia \\ ${ }^{3}$ RM Gorbacheva Research Institute of Pediatric Oncology, Hematology and Transplantation, Pavlov University, St. Petersburg, \\ Russia \\ ${ }^{4}$ V. A. Almazov National Medical Research Center, St. Petersburg, Russia \\ ${ }^{5}$ St. Petersburg State Pediatric Medical University, St. Petersburg, Russia \\ ${ }^{6}$ N. N. Blokhin National Medical Research Center of Oncology, Moscow, Russia
}

Dr. Liudmila V. Olkhova, Pediatric Oncologist, Department of Bone Marrow Transplantation, Russian Pediatric Clinical Hospital, N. N. Pirogov Russian National Medical University, Leninsky Ave 117, 119571, Moscow, Russia
Phone: +7 (995) 7075140

E-mail: rylkova87@mail.ru

Citation: Olkhova LV, Zheludkova OG, Zubarovskaya LS et al. High-dose chemotherapy with autologous hematopoietic stem cell transplantation in children with atypical teratoid/rhabdoid CNS tumors. Cell Ther Transplant 2021; 10(1): 44-54.

\section{Summary}

Atypical teratoid rhabdoid tumor (ATRT) of central nervous system (CNS) is an aggressive malignancy with poor prognosis, predominantly observed in young children. There are no established approaches to CNS ATRT management nowadays. This retrospective study aimed to analyze the effectiveness and prognostic factors of high dose chemotherapy with autologous hematopoietic stem cell transplantation HDCT/auto-HSCT in pediatric CNS ATRT. Thirty CNS ATRT patients treated with HDCT/auto-HSCT were enrolled in the analysis. Median age was 19.5 months. There were $11(36.6 \%)$ infants and $19(63.4 \%)$ children older than 12 months, among them $21(70 \%)$ boys and $9(30 \%)$ girls. Infratentorial tumor was diagnosed in 7 patients $(56.7 \%)$ and supratentorial in $13(43.3 \%)$. All children initially received surgery with total resection $(\mathrm{n}=8,26.7 \%)$, subtotal resection $(n=9,30 \%)$, partial resection $(n=11,36.6 \%)$ and biopsy $(n=2,6.7 \%)$. The majority of patients had $M+$ stage $(n=16,53.3 \%)$ and the minority had M-0 stage $(n=12$, $40 \%)$, while stage wasn't clarified $(\mathrm{Mx})$ in $2(6.7 \%)$ cases. After surgery everyone received treatment according to various protocols: EU-RHAB ( $\mathrm{n}=12,40 \%)$, MUV-ATRT $(\mathrm{n}=11,36.7 \%)$, individual therapy $(\mathrm{n}=7,23.3 \%)$. Radiotherapy (RT) was performed in 24 children (80\%) after HDCT/auto-HSCT. The majority of patients $(n=22$, $73.3 \%$ ) received intraventricular/intrathecal chemotherapy. The disease status was assessed in all cases prior to HDCT/auto-HSCT with complete response (CR) in 12 (40\%), partial response (PR) in $8(26.7 \%)$ and stabilization (S) in $10(33.3 \%)$. Single auto-HSCT was performed in the majority of patients $(n=21,70 \%)$ and tandem transplants were carried out in 9 cases only (30\%). In total, 39 transplants were performed. Peripheral blood hematopoietic stem cells (PBSC) were the transplant source in 27 children (90\%), and combination of PBSC and bone marrow (BM), in 3 (10\%). Five-year eventfree survival (EFS) and overall survival (OS) were $44 \%$. The majority of relapses were diagnosed during first 24 months after disease onset. These data are comparable to the most international results. Survival of CNS ATRT patients after HDCT/auto-HSCT was statistically significantly higher after total tumor resection, RT, intraventricular/intrathecal chemotherapy, and CR prior to transplantation. 


\section{Keywords}

Children, young age, atypical teratoid rhabdoid tumor, central nervous system, chemotherapy, high-dose, radiation therapy, clinical outcomes, survival, prognostic factors.

\section{Introduction}

Central nervous system (CNS) atypical teratoid rhabdoid tumor (ATRT) is a rare aggressive malignancy, which comprises $1-2 \%$ of brain and spinal neoplasms [1,2]. Median age at diagnosis is 1 year with male predominance 1.5:1.3 [3, 4, $5,6]$. Nowadays, there are no established standards in the treatment of CNS ATRT. Various management approaches exist for different countries and institutions. Despite this uncertainty, surgery followed by adjuvant chemotherapy and radiotherapy (in older children) is, without doubt, the cornerstone of their treatment $[7,8]$. HDCT/auto-HSCT is used in children under 3 years, intending for canceling or postponing radiation therapy (RT) and reduce the risk of longterm neuro-cognitive disorders and improve outcome $[9,10$, 11]. Despite intensive multimodal therapy, the majority of patients with ATRT develop relapses [10,11,12]. Prognosis for CNS ATRT remains dismal, especially in children with residual tumor and metastatic disease.

The aim of present study was to assess effectiveness and define prognostic factors in CNS ATRT patients after HDCT/ auto-HSCT.

\section{Patients and methods}

\section{Trial design}

This retrospective multicentric continuous cooperative study was performed between 2008 and 2020 in V.A. Almazov NMRC, RM Gorbacheva Research Institute, Pavlov University, and Pirogov Russian National Research Medical University. Eligibility criteria: the study included 30 patients aged $\leq 18$ with histologically verified CNS ATRT and complex treatment performed according to different protocols, including HDCT/auto-HSCT.

The surviving patients were censored by 1 February 2021 . Overall survival was calculated from the date of surgery up to death or up to the last follow up. Event-free survival was calculated from the date of surgery up to the date of unfavorable event (death, relapse, progression), or up to last follow up.

\section{Clinical characteristics of patients}

A total of 30 patients $\leq 18$ years old with median age of 19.5 months were enrolled in the study from different regions of Russian Federation. Initial characteristics of patients are presented in Table 1. There were 11 (36.6\%) infants, and 19 (63.4\%) children aged over 12 months, among them 21 (70\%) boys and $9(30 \%)$ girls. Infratentorial tumor was diagnosed in 7 patients (56.7\%) and supratentorial - in 13 (43.3\%).
Molecular biologic subgroups were identified only in $7 \mathrm{pa}-$ tients: ATRT-SHH $(\mathrm{n}=4)$, ATRT-MYC $(\mathrm{n}=1)$ and ATRT TYR $(n=2)$. All children initially received surgery with total tumor resection $(n=8,26.7 \%)$, subtotal resection $(n=9$, $30.0 \%)$, partial resection $(\mathrm{n}=11,36.6 \%)$ and biopsy $(\mathrm{n}=2$, $6.7 \%)$. The majority of patients had $M+$ stage $(n=16,53.3 \%)$ and minor subgroup had M-0 stage $(\mathrm{n}=12,40 \%)$, with non-classified stage $(\mathrm{Mx})$ in 2 cases $(6.7 \%)$. After surgery, everyone received treatment according to various protocols: EU-RHAB $(\mathrm{n}=12,40 \%)$, MUV-ATRT $(\mathrm{n}=11,36.7 \%)$, individual therapy $(\mathrm{n}=7,23.3 \%)$. There was no radiotherapy $(\mathrm{RT})$ prior to HDCT/auto-HSCT in children with ATRT. RT after transplantation was performed in 24 children (80\%): local RT $(\mathrm{n}=16,60 \%)$, cranio-spinal irradiation $(\mathrm{n}=6,20 \%)$, and no RT $(\mathrm{n}=6,20 \%)$. The majority of patients $(\mathrm{n}=22,73.3 \%)$ received intraventricular/intrathecal chemotherapy. Disease status was assessed in all 12 cases (40\%) prior to HDCT/ auto-HSCT with complete response (CR); partial response (PR), in 8 (26.7\%), and stabilization (S) in 10 (33.3\%). Single auto-HSCT was performed in majority of patients $(\mathrm{n}=21$, $70 \%$ ), and tandem transplant, only in 9 cases (30\%). Total number of transplants was 39 . Prior to auto-HSCT peripheral blood hematopoietic stem cells (PBSC) or bone marrow (BM) were harvested. PBSC were the transplant source in 27 children (90\%), and combination of PBSC and BM was used in 3 cases (10\%).

Conditioning regimen for single auto-HSCT in the majority of cases $(\mathrm{n}=13,43.3 \%)$ consisted of thiotepa $300 \mathrm{mg} / \mathrm{m}^{2}$, carboplatin $500 \mathrm{mg} / \mathrm{m}^{2}$ and etoposide $250 \mathrm{mg} / \mathrm{m}^{2}$ on Days $-6,-5,-4$ (Table 2). Carboplatin $500 \mathrm{mg} / \mathrm{m} 2$ and thiotepa $300 \mathrm{mg} / \mathrm{m} 2$ on Days $-6,-5,-4$ were used in 8 patients (26.7\%). First conditioning regimen consisted of carboplatin $500 \mathrm{mg} / \mathrm{m}^{2}$ and etoposide $250 \mathrm{mg} / \mathrm{m}^{2}$ on Days $-8,-7,-6,-5$ and second conditioning regimen consisted of thiotepa 300 $\mathrm{mg} / \mathrm{m} 2$ and cyclophosphamide $1500 \mathrm{mg} / \mathrm{m}^{2}$ on Days $-4,-3,-2$ in 7 children $(23.3 \%)$ with tandem transplantation. Carboplatin $510 \mathrm{mg} / \mathrm{m}^{2}$ and thiotepa $300 \mathrm{mg} / \mathrm{m}^{2}$ on Days $-4,-3$ for both transplantations were used in 2 patients $(6.7 \%)$. Time interval between first and second HDCT was 4-6 weeks. Chemotherapy was calculated according to pre-transplant levels of glomerular filtration rate, cardiac output and audiometry. Mean number of infused CD34+ cells was $4.98 \times 10^{6} / \mathrm{kg}(1.9-9.2)$.

\section{Statistical evaluation}

Data collection and clarification, systematization of initial information and visualization in digital tables were performed by means of Microsoft Office Excel (2016). Python was used for statistical analysis (Python 3.8.). Calculations were based on built-in function modules (Scipy and Lifelines). 
Table 1. Characteristics of CNS ATRT patients and HDCT/auto-HSCT

\begin{tabular}{|c|c|c|}
\hline \multirow[t]{2}{*}{ Parameter } & \multicolumn{2}{|c|}{ Value } \\
\hline & Number & $\%$ \\
\hline \multicolumn{3}{|c|}{ Sex $(n=30)$} \\
\hline Male & 21 & $70 \%$ \\
\hline Female & 9 & $30 \%$ \\
\hline \multicolumn{3}{|c|}{ Age at diagnosis $(\mathrm{n}=30)$} \\
\hline$<12$ months & 11 & $36.6 \%$ \\
\hline$>12$ months & 19 & $63.4 \%$ \\
\hline Range (min-max), months & \multicolumn{2}{|c|}{$1-64$} \\
\hline Median, months & \multicolumn{2}{|c|}{19.5} \\
\hline \multicolumn{3}{|c|}{ Tumor localization $(n=30)$} \\
\hline Infratentorial & 17 & $56.7 \%$ \\
\hline Supratentorial & 13 & $43.3 \%$ \\
\hline \multicolumn{3}{|c|}{ Stage $(n=30)$} \\
\hline M0 & 12 & $40 \%$ \\
\hline$M+$ & 16 & $53.3 \%$ \\
\hline$M x$ & 2 & $6.7 \%$ \\
\hline \multicolumn{3}{|c|}{ Tumor resection $(n=30)$} \\
\hline Total resection & 8 & $26.7 \%$ \\
\hline Subtotal resection & 9 & $30 \%$ \\
\hline Partial resection & 11 & $36.6 \%$ \\
\hline Biopsy & 2 & $6.7 \%$ \\
\hline \multicolumn{3}{|c|}{ Chemotherapy protocol ( $n=30)$} \\
\hline EU-RHAB & 12 & $40 \%$ \\
\hline MUV-ATRT & 11 & $36.7 \%$ \\
\hline Individual therapy & 7 & $23.3 \%$ \\
\hline \multicolumn{3}{|c|}{ Radiotherapy (n=30) } \\
\hline Local RT & 18 & $60 \%$ \\
\hline Craniospinal irradiation & 6 & $20 \%$ \\
\hline No RT & 6 & $20 \%$ \\
\hline \multicolumn{3}{|c|}{ Intraventricular/intrathecal chemotherapy $(n=30)$} \\
\hline Yes & 22 & $73.3 \%$ \\
\hline No & 8 & $26.7 \%$ \\
\hline \multicolumn{3}{|c|}{ Status prior to HDCT/auto-HSCT (n=30) } \\
\hline Complete response & 12 & $40 \%$ \\
\hline Stabilization & 10 & $33.3 \%$ \\
\hline Partial response & 8 & $26.7 \%$ \\
\hline \multicolumn{3}{|c|}{ Stem cell source $(n=30)$} \\
\hline PBSC & 27 & $90 \%$ \\
\hline $\mathrm{PBSC}+\mathrm{BM}$ & 3 & $10 \%$ \\
\hline
\end{tabular}

Table 2. Conditioning regimens for HDCT/auto-HSCT in CNS ATRT patients.

\begin{tabular}{|c|c|c|c|}
\hline Drugs & Route of administration & Total dosage $\left(\mathrm{mg} \backslash \mathrm{m}^{2}\right)$ & Number of patients (\%) \\
\hline \multicolumn{4}{|c|}{ Single HDCT } \\
\hline $\begin{array}{l}\text { Carboplatin } \\
\text { Etoposide } \\
\text { Thiotepa }\end{array}$ & $\begin{array}{l}\text { intravenous } \\
\text { intravenous } \\
\text { intravenous }\end{array}$ & $\begin{array}{l}1500 \\
750 \\
900\end{array}$ & $13(43.3 \%)$ \\
\hline $\begin{array}{l}\text { Carboplatin } \\
\text { Thiotepa }\end{array}$ & $\begin{array}{l}\text { intravenous } \\
\text { intravenous }\end{array}$ & $\begin{array}{l}1500 \\
900\end{array}$ & $8(26.7 \%)$ \\
\hline \multicolumn{4}{|c|}{ Tandem HDCT } \\
\hline $\begin{array}{l}\text { 1. HDCT } \\
\text { Carboplatin } \\
\text { Etoposide } \\
\text { 2. HDCT } \\
\text { Thiotepa } \\
\text { Cyclophosphamide }\end{array}$ & $\begin{array}{l}\text { intravenous } \\
\text { intravenous } \\
\text { intravenous } \\
\text { intravenous }\end{array}$ & $\begin{array}{l}2000 \\
1000 \\
900 \\
4500 \\
\end{array}$ & $7(23.3 \%)$ \\
\hline $\begin{array}{l}2 \text { cycles of HDCT: } \\
\text { Carboplatin } \\
\text { Thiotepa }\end{array}$ & $\begin{array}{l}\text { intravenous } \\
\text { intravenous }\end{array}$ & $\begin{array}{l}1020 \\
600\end{array}$ & 2 (6.7\%) \\
\hline
\end{tabular}


The Shapiro-Wilk test demonstrated absence of normal distribution of data in the study. It required usage of non-parametric statistics for further analysis.

The surviving patients were censored by 1 February 2021. Overall survival was calculated from the date of surgery up to death or last follow-up. Event-free survival was calculated from the date of intervention up to the date of unfavorable event (death, relapse, progression), or to the last follow-up. Median values describe the central values of distribution. Quantiles (Me [Q1; Q3]) and range of variation were used for assessment of variables. Mann-Whitney U-test compared independent samples in the absence of normal distribution. Nominal data obtained for independent research groups were compared using Pearson's Chi-squared test. Survival and cumulative incidence of events were calculated according to Kaplan-Meier method. Survival curves were compared using the log-rank test. Clinical outcomes were analyzed by multifactorial analysis (Cox regression). Stepwise regression was chosen for regression assessment, starting with maximal number of predictors. At each next step, the model excludes less valuable predictors. The procedure was stopped when the only independent variables remained, that were statistically significant. Statistical significance was assumed at $\mathrm{p}$-value of $\leq 0.05$.

\section{Results}

At the time of analysis, 18 children (60\%) were alive and 12 (40\%) died, among them 11 (91.6\%) succumbed to ATRT progression and $1(8.4 \%)$ to infectious complications in early post-trasnplant period. There were no cases of secondary tumors. Among children of ATRT-SHH molecular subgroup 2 died of progression and 2 were alive and in remission. Patient with ATRT-MYC molecular subgroup died of progression and 2 children with ATRT TYR stayed alive and in remission at the last follow up.

According to Kaplan-Meier statistical method EFS of the whole cohort $(\mathrm{n}=30)$ was $0.87[0.68 ; 0.95]$ at 1 year, $0.49[0.3$; $0.67]$ at 2 years and $0.44[0.24 ; 0.62]$ at 5 years (Fig. 1 ). Median EFS was 23 months $[16.0 ; 102]$. Worth of note, the majority of relapses in children with CNS ATRT occured during first 24 months after diagnosis.
OS was $0.97[0.79 ; 1.0]$ at 1 year, $0.7[0.49 ; 0.84]$ at 2 years, $0.44[0.22 ; 0.64]$ at 5 years (Fig. 2). Median OS was 44 months $[22.0 ; 102]$.

Analysis of prognostic factors in CNS ATRT patients after HDCT/auto-HSCT was performed. The results of univariate analysis are presented in Table 3.

In univariate analysis extent of resection, radiotherapy, intraventricular/intrathecal chemotherapy and disease status prior to auto-HSCT demonstrated statistically significant impact on EFS. Survival curves are presented on Figures 3a-3d.

Upon univariate analysis, EFS in patients with CNS ATRT after HDCT/auto-HSCT was statistically significantly higher after total resection compared to subtotal resection, partial resection or biopsy: $1.0[1.0 ; 1.0] ; 0.37$ [0.07; 0.69]; 0.15 [0.01; 0.46 ]; 0,00 [0.00; 0.00], respectively $(\mathrm{p}<0.001)$ (Fig. $3 \mathrm{~A})$; in the patients with RT versus children without RT: 0.56 [0.31; $0.75]$ and 0.00 [0.00;0.00], respectively $(\mathrm{p}<0.001)$ (Fig. 3B); in the patients with intraventricular/intrathecal chemotherapy than in children without this local approach: 0.55 [0.29; $0.75]$ and 0.13 [0.01;0.42], respectively ( $p=0.0005)$ (Fig. 3C); and in complete responders prior to auto-HSCT compared to PR and stable disease: 0.88 [0.39; 0.98]; $0.0[0.0 ; 0.0]$ and $0.47[0.12 ; 0.76]$, respectively $(\mathrm{p}<0.001)$, as seen from Fig. $3 \mathrm{D}$.

Such factors as extent of tumor resection, radiotherapy, intraventricular/intrathecal chemotherapy, disease status prior to HDCT demonstrated statistically significant impact on OS (the survival curves are shown on Figures $4 \mathrm{~A}$ to $4 \mathrm{D}$ ).

Upon univariate analysis, OS in CNS ATRT patients after HDCT/auto-HSCT was statistically significantly higher after total resection compared to subtotal resection, partial resection or biopsy: $1.0[1.0 ; 1.0] ; 0.62[0.23 ; 0.86] ; 0.0[0.0 ; 0.0]$; $0,00[0.00 ; 0.00] 0,00[0.00 ; 0.00]$, respectively $(\mathrm{p}<0.001)$, as senn in Fig. 4A; in the patients with RT compared to children without RT: 0.57 [0.29; 0.78] and 0,00 [0.00;0.00], respectively $(\mathrm{p}<0.001)$ depicted in Fig. $4 \mathrm{~B}$; in the patients with intraventricular/intrathecal chemotherapy than in children without this local approach: $0.56[0.25 ; 0.78]$ and $0.13[0.01$; 0.42 ], respectively ( $\mathrm{p}=0.0001$, Fig. $4 \mathrm{C}$ ); and in complete responders prior to auto-HSCT compared to PR and stable disease: $1.0[1.0 ; 1.0] ; 0.0[0.0 ; 0.0]$ and $0.0[0.0 ; 0.0]$, respectively $(\mathrm{p}<0.001)$, as shown in Fig. $4 \mathrm{D}$.

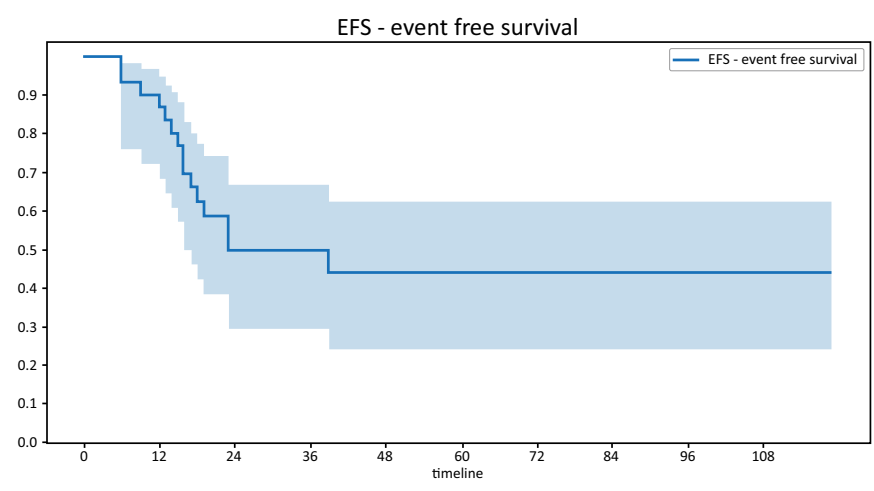

Figure 1. Event-free survival (EFS) of CNS ATRT patients after HDCT/auto-HSCT

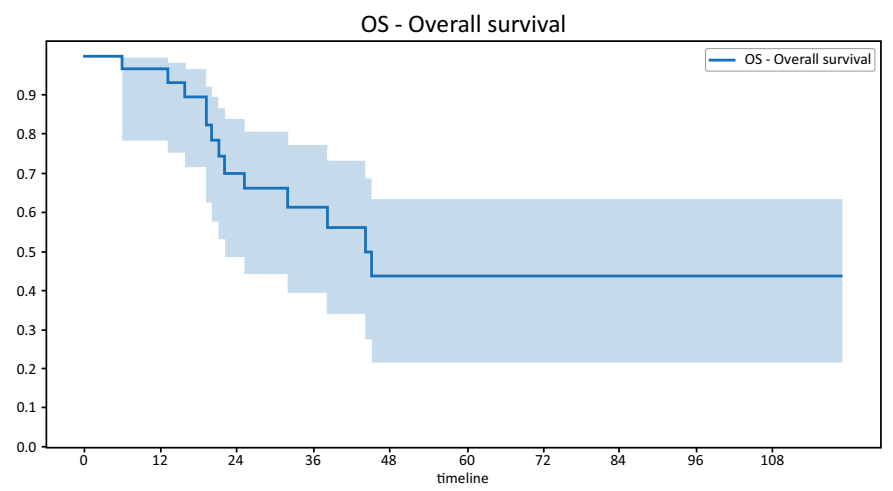

Figure 2. Overall survival in CNS ATRT patients after HDCT/auto-HSCT 
Table 3. Prognosis of CNS ATRT patients after HDCT/auto-HSCT according to different factors

\begin{tabular}{|c|c|c|c|c|c|c|}
\hline \multirow[b]{2}{*}{ Factors } & \multicolumn{3}{|c|}{ Event free survival (EFS) } & \multicolumn{3}{|c|}{ Overall survival (OS) } \\
\hline & $\begin{array}{l}\text { Median survival } \\
{[95 \% \mathrm{Cl}]}\end{array}$ & $\begin{array}{l}\text { Median time, } \\
\text { months } \\
{[95 \% \mathrm{Cl}]}\end{array}$ & Log Rank, $p$ & $\begin{array}{l}\text { Median survival } \\
{[95 \% \mathrm{Cl}]}\end{array}$ & $\begin{array}{l}\text { Median time, } \\
\text { months } \\
{[95 \% \mathrm{Cl}]}\end{array}$ & Log Rank, p \\
\hline $\begin{array}{l}\text { Age } \\
<12 \text { months }(n=11) \\
>12 \text { months }(n=19)\end{array}$ & $\begin{array}{l}0.62[0.28 ; 0.84] \\
0.32[0.1 ; 0.57]\end{array}$ & $\begin{array}{l}-[12.0 ;-] \\
23.0[16.0 ;-]\end{array}$ & 0.3866 & $\begin{array}{l}0.52[0.15 ; 0.8] \\
0.37[0.13 ; 0.62]\end{array}$ & $\begin{array}{l}-[16.0 ;-] \\
38.0[20.0 ;-]\end{array}$ & 0.5569 \\
\hline $\begin{array}{l}\text { Sex } \\
\text { Male }(n=21) \\
\text { Female }(n=9)\end{array}$ & $\begin{array}{l}0.55[0.31 ; 0.74] \\
0.33[0.08 ; 0.62]\end{array}$ & $\begin{array}{l}-[15.0 ;-] \\
23.0[6.0 ;-]\end{array}$ & 0.7295 & $\begin{array}{l}0.48[0.2 ; 0.72] \\
0.42[0.11 ; 0.71]\end{array}$ & $\begin{array}{l}44.0[19.0 ;-] \\
45.0[20.0 ;-]\end{array}$ & 0.8184 \\
\hline $\begin{array}{l}\text { Tumor localization } \\
\text { Infratentorial }(n=17) \\
\text { Supratentorial }(n=13)\end{array}$ & $\begin{array}{l}0.51[0.26 ; 0.72] \\
0.23[0.01 ; 0.6]\end{array}$ & $\begin{array}{l}-[14.0 ;-] \\
23.0[16.0 ;-]\end{array}$ & 0.6511 & $\begin{array}{l}0.45[0.18 ; 0.68] \\
0.4[0.08 ; 0.73]\end{array}$ & $\begin{array}{l}45.0[21.0 ;-] \\
38.0[19.0 ;-]\end{array}$ & 0.7290 \\
\hline $\begin{array}{l}\text { Stage } \\
M 0(n=12) \\
M+\text { or multifocal tumor }(n=16) \\
M x(n=2)\end{array}$ & $\begin{array}{l}0.46[0.16 ; 0.72] \\
0.52[0.24 ; 0.74] \\
0.0[0.0 ; 0.0]\end{array}$ & $\begin{array}{l}39.0[12.0 ;-] \\
-[17.0 ;-] \\
9.0[9.0 ; 23.0]\end{array}$ & 0.322 & $\begin{array}{l}0.52[0.2 ; 0.77] \\
0.41[0.11 ; 0.7] \\
0.0[0.0 ; 0.0]\end{array}$ & $\begin{array}{l}-[19.0 ;-] \\
45.0[22.0 ;-] \\
13.0[13.0 ; 38.0]\end{array}$ & 0.1952 \\
\hline $\begin{array}{l}\text { Extent of resection } \\
\text { Total }(n=8) \\
\text { Subtotal }(n=9) \\
\text { Partial }(n=11) \\
\text { Biopsy }(n=2)\end{array}$ & $\begin{array}{l}1.0[1.0 ; 1.0] \\
0.37[0.07 ; 0.69] \\
0.15[0.01 ; 0.46] \\
0.00[0.00 ; 0.00]\end{array}$ & $\begin{array}{l}-[-;-] \\
39.0[6.0 ;-] \\
19.0[14.0 ; 23.0] \\
6.0[6.0 ; 12.0]\end{array}$ & $<0.001^{\star}$ & $\begin{array}{l}1.0[1.0 ; 1.0] \\
0.62[0.23 ; 0.86] \\
0.0[0.0 ; 0.0] \\
0.0[0.0 ; 0.0]\end{array}$ & $\begin{array}{l}-[-;-] \\
-[19.0 ;-] \\
32.0[19.0 ; 45.0] \\
6.0[6.0 ; 16.0]\end{array}$ & $<0.001^{\star}$ \\
\hline $\begin{array}{l}\text { Chemotherapy protocol } \\
\text { EU-RHAB ( } n=12) \\
\text { MUV-ATRT ( } n=11) \\
\text { Individual therapy }(n=7)\end{array}$ & $\begin{array}{l}0.4[0.14 ; 0.66] \\
0.7[0.33 ; 0.89] \\
0.29[0.04 ; 0.61]\end{array}$ & $\begin{array}{l}15.0[9.0 ;-] \\
-[16.0 ;-] \\
23.0[6.0 ;-]\end{array}$ & 0.1826 & $\begin{array}{l}0.32[0.08 ; 0.6] \\
0.5[0.06 ; 0.84] \\
0.43[0.1 ; 0.73]\end{array}$ & $\begin{array}{l}21.0[13.0 ;-] \\
45.0[44.0 ;-] \\
38.0[20.0 ;-]\end{array}$ & 0.0854 \\
\hline $\begin{array}{l}\text { Radiotherapy } \\
\text { Radiotherapy + (n=24) } \\
\text { Radiotherapy - (n=6) }\end{array}$ & $\begin{array}{l}0.56[0.31 ; 0.75] \\
0.0[0.0 ; 0.0]\end{array}$ & $\begin{array}{l}-[19.0 ;-] \\
12.0[6.0 ; 23.0]\end{array}$ & $<0.001^{\star}$ & $\begin{array}{l}0.57[0.29 ; 0.78] \\
0.0[0.0 ; 0.0]\end{array}$ & $\begin{array}{l}-[32.0 ;-] \\
19.0[6.0 ; 38.0]\end{array}$ & $<0,001^{\star}$ \\
\hline $\begin{array}{l}\text { Intraventricular/intrathecal } \\
\text { chemotherapy } \\
\text { Yes }(n=22) \\
\text { No }(n=8)\end{array}$ & $\begin{array}{l}0.55[0.29 ; 0.75] \\
0.13[0.01 ; 0.42]\end{array}$ & $\begin{array}{l}-[23.0 ;-] \\
15.0[6.0 ; 17.0]\end{array}$ & $0.0005^{\star}$ & $\begin{array}{l}0.56[0.25 ; 0.78] \\
0.13[0.01 ; 0.42]\end{array}$ & $\begin{array}{l}-[38.0 ;-] \\
19.0[6.0 ; 22.0]\end{array}$ & $0.0001^{\star}$ \\
\hline $\begin{array}{l}\text { Disease status prior } \\
\text { to HDCT/auto-HSCT } \\
\text { Complete response }(n=12) \\
\text { Stabilization }(n=10) \\
\text { Partial response }(n=8)\end{array}$ & $\begin{array}{l}0.88[0.39 ; 0.98] \\
0.0[0.0 ; 0.0] \\
0.47[0.12 ; 0.76]\end{array}$ & $\begin{array}{l}-[39.0 ;-] \\
13.0[6.0 ; 19.0] \\
18.0[14.0 ;-]\end{array}$ & $<0.001^{\star}$ & $\begin{array}{l}1.0[1.0 ; 1.0] \\
0.0[0.0 ; 0.0] \\
0.0[0.0 ; 0.0]\end{array}$ & $\begin{array}{l}-[-;-] \\
19.0[6.0 ; 32.0] \\
45.0[20.0 ; 45.0]\end{array}$ & $<0.001^{*}$ \\
\hline $\begin{array}{l}\text { Single/Tandem auto-HSCT } \\
\text { Single }(n=21) \\
\text { Tandem }(n=9)\end{array}$ & $\begin{array}{l}0.43[0.18 ; 0.67] \\
0.44[0.14 ; 0.72]\end{array}$ & $\begin{array}{l}39.0[16.0 ;-] \\
23.0[12.0 ;-]\end{array}$ & 0.9284 & $\begin{array}{l}0.39[0.11 ; 0.67] \\
0.44[0.14 ; 0.72]\end{array}$ & $\begin{array}{l}45.0[22.0 ;-] \\
38.0[16.0 ;-]\end{array}$ & 0.8775 \\
\hline $\begin{array}{l}\text { Stem cell source } \\
\text { PBSC }(n=27) \\
B M+P B S C(n=3)\end{array}$ & $\begin{array}{l}0.5[0.28 ; 0.69] \\
0.0[0.0 ; 0.0]\end{array}$ & $\begin{array}{l}-[16.0 ;-] \\
19.0[6.0 ; 23.0]\end{array}$ & 0.1006 & $\begin{array}{l}0.53[0.29 ; 0.73] \\
0.0[0.0 ; 0.0]\end{array}$ & $\begin{array}{l}-[21.0 ;-] \\
38.0[25.0 ; 44.0]\end{array}$ & 0.2450 \\
\hline
\end{tabular}



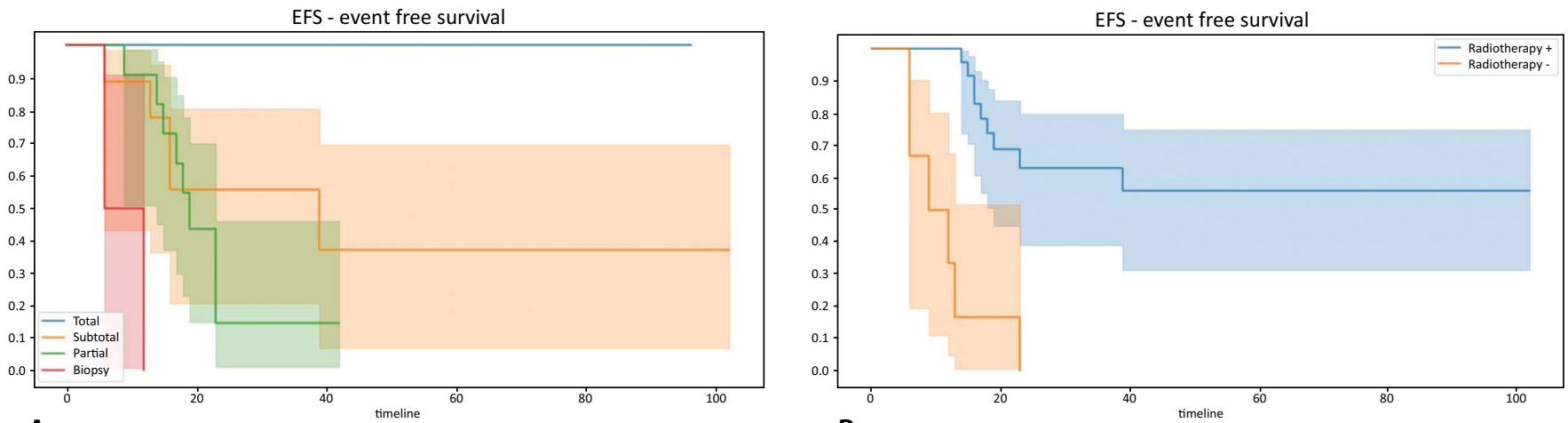

A

B
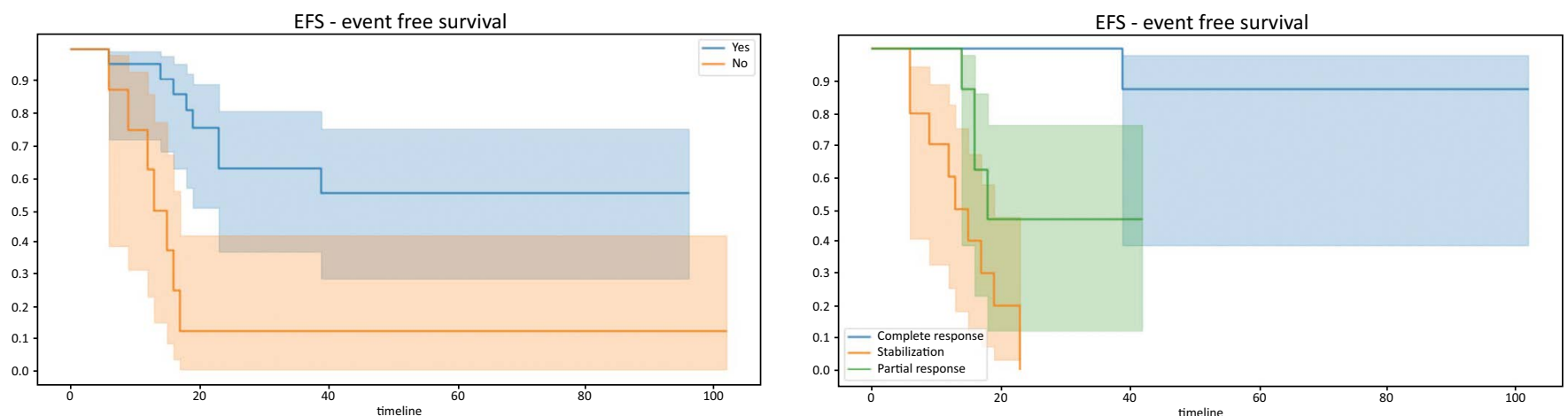

C

D

Figure 3. Event-free survival in CNS ATRT patients after HDCT/auto-HSCT according to different factors: a - extent of resection; b - radiotherapy, $c$ - intraventricular/intrathecal chemotherapy; $d$ - disease status prior to auto-HSCT

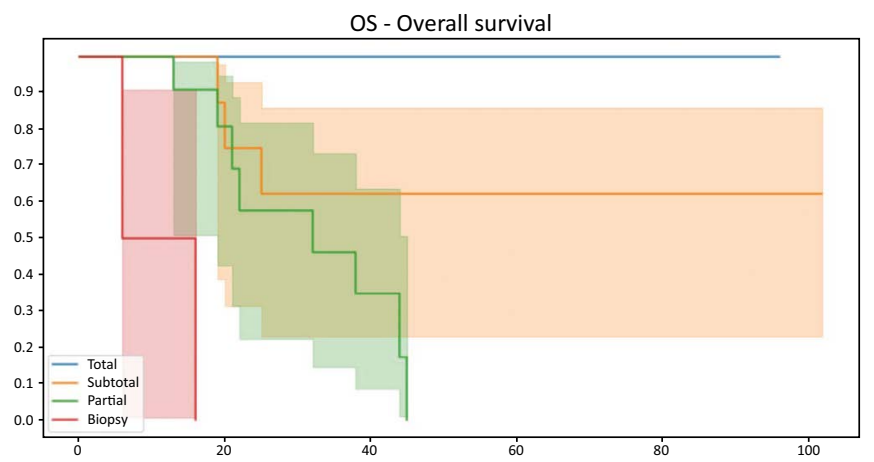

A

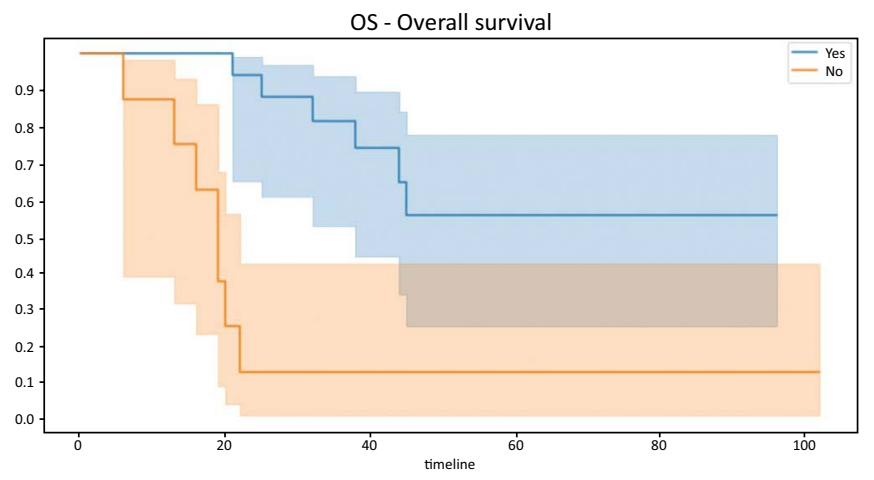

C

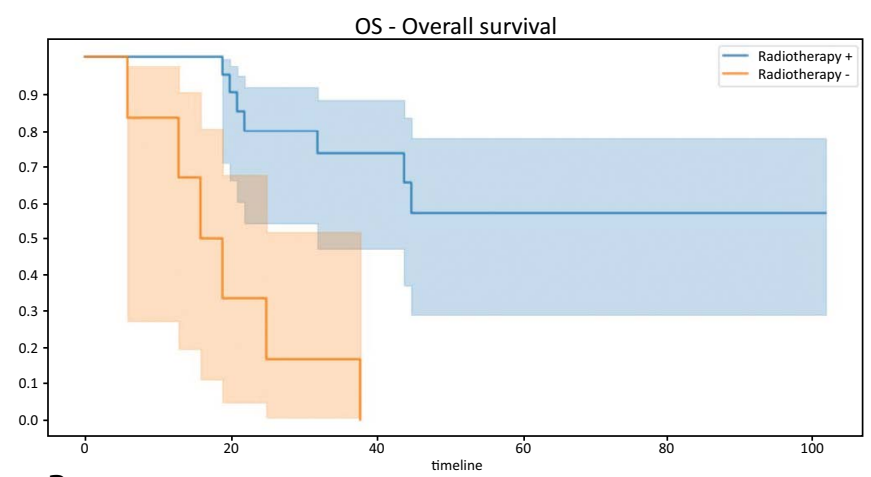

B

OS - Overall survival

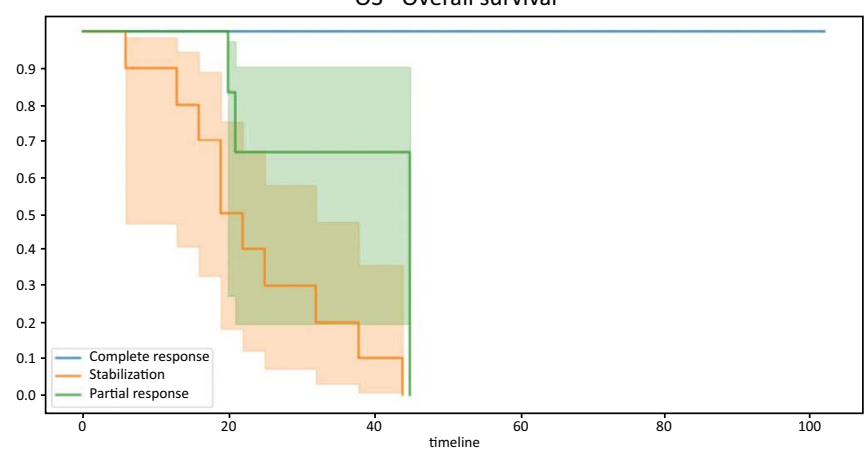

D

Figure 4. Overall survival of CNS ATRT patients after HDCT/auto-HSCT according to different factors: a, extent of tumor resection; b, radiotherapy; c, intraventricular/intrathecal chemotherapy; d, disease status prior to auto-HSCT 
A
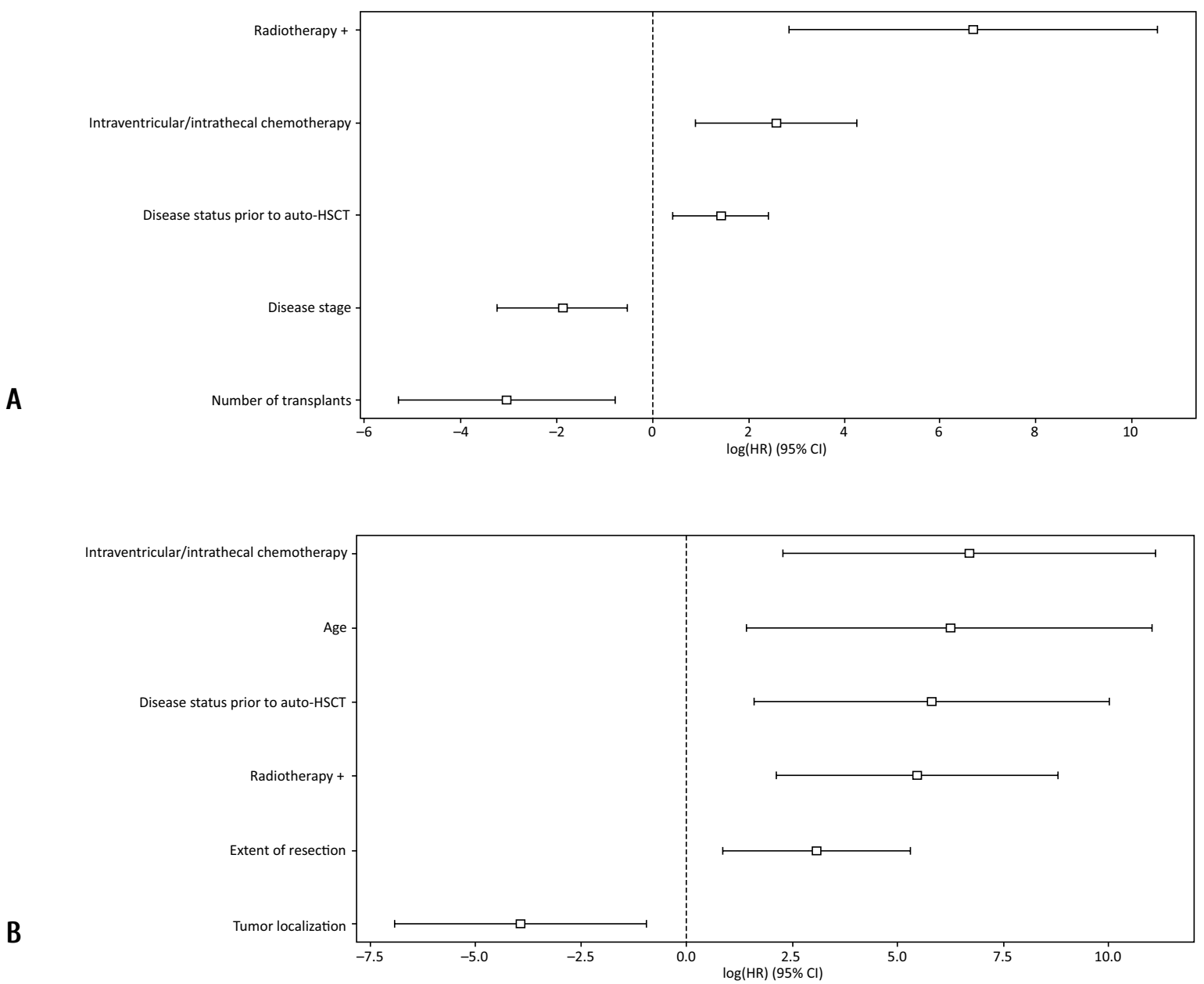

Figure 5. Multivariate analysis of EFS (a) and OS (b) by Cox Proportional Hazard Model

Figure 5A demonstrates that final model of EFS includes such variables as RT, disease stage, intraventricular/intrathecal chemotherapy, disease status prior to auto-HSCT, number of transplants.

Figure 5B demonstrates that final model of OS includes age, tumor localization, extent of resection, radiotherapy, intraventricular/intrathecal chemotherapy and disease status prior to auto-HSCT.

Duration of cytopenia varied from 6 to 24 days with median of 11 days after hematopoietic stem cell reinfusion. Toxicity of HDCT/auto-HSCT was assessed according to international criteria (CTCAE v.4.0), with the following items: ototoxicity, neurotoxicity, infections, nephrotoxicity, nausea/vomiting, mucositis, skin toxicity, hepatotoxicity, lung toxicity, cardiotoxicity.

During the study period, 21 single and 9 tandem transplants were performed in 30 patients. Total number of transplants reached 39, and they were separately analyzed according to 5-scale CTCAE recommendations. Distribution according to toxicity was as follows: Grade I - $32 \%(n=58)$, Grade II $46 \%(n=83)$, Grade III - 15\% $(n=27)$ and Grade IV - 7\% $(n=13)$ as shown in Fig. 6.

Fig. 7 demonstrates that that the majority of Stage IV complications were mucositis and infections (sepsis).

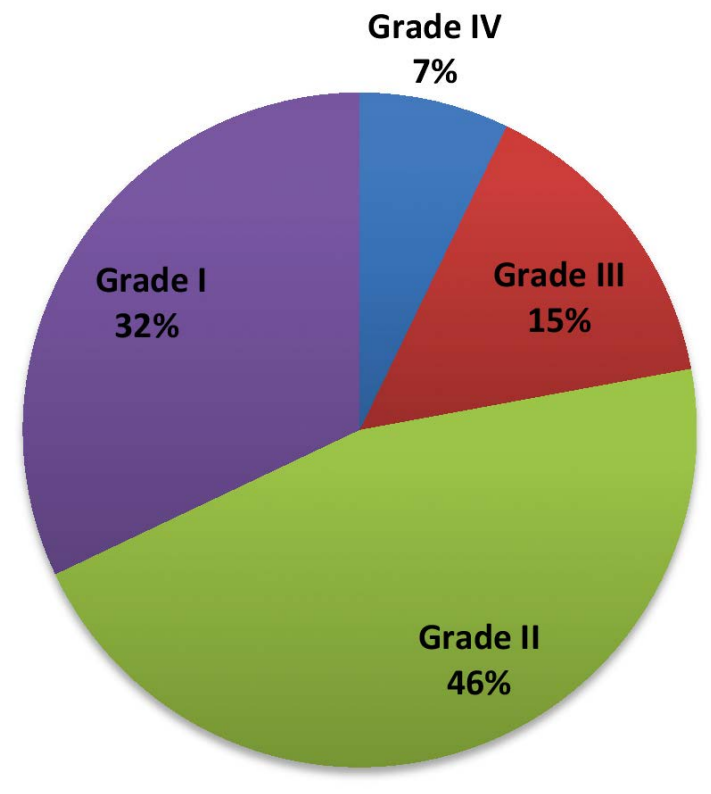

Figure 6. Toxicity distribution according to CTCAE in CNS ATRT patients after HDCT/auto-HSCT 


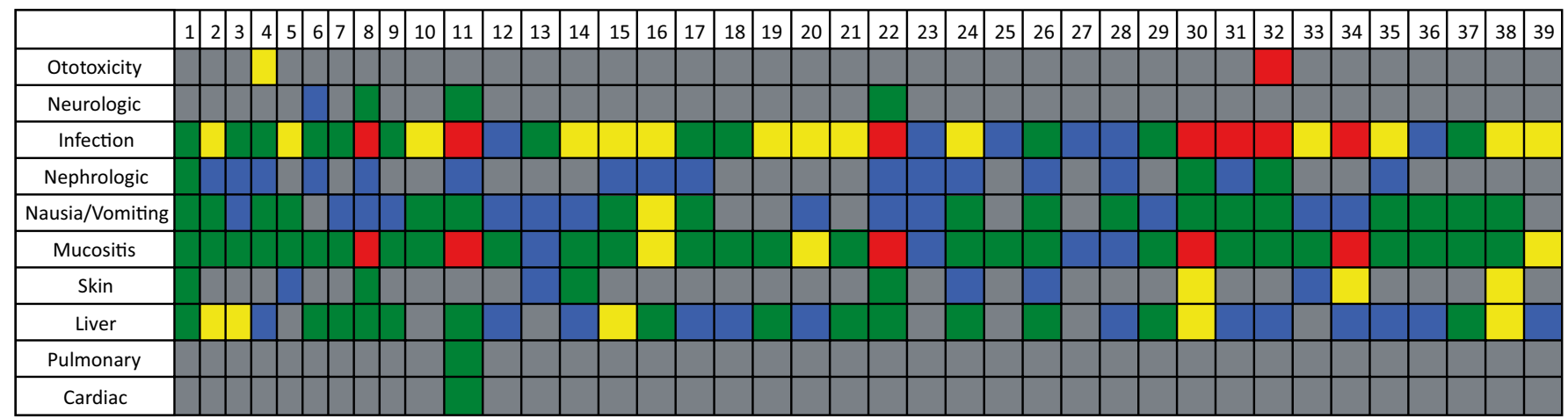

Figure 7. Toxicity distribution according to grade, organs and systems in CNS ATRT patients after HDCT/auto-HSCT

Note: Grade 0, marked grey; Grade I, blue; Grade II, green; Grade III, yellow, and Grade IV, in red colour

Distribution of Grade II-IV toxicity, of the most commonly affected organs and systems was as follows: gastrointestinal mucositis $(90 \%, \mathrm{n}=35)$, infectious complications $(85 \%$, $\mathrm{n}=33)$, nausea/vomiting ( $49 \%, \mathrm{n}=19)$, hepatotoxicity $(49 \%$, $\mathrm{n}=19)$ as shown in Fig. 8.

There were no statistically significant differences in organ and system toxicity after single versus tandem transplants (Fig. 9).

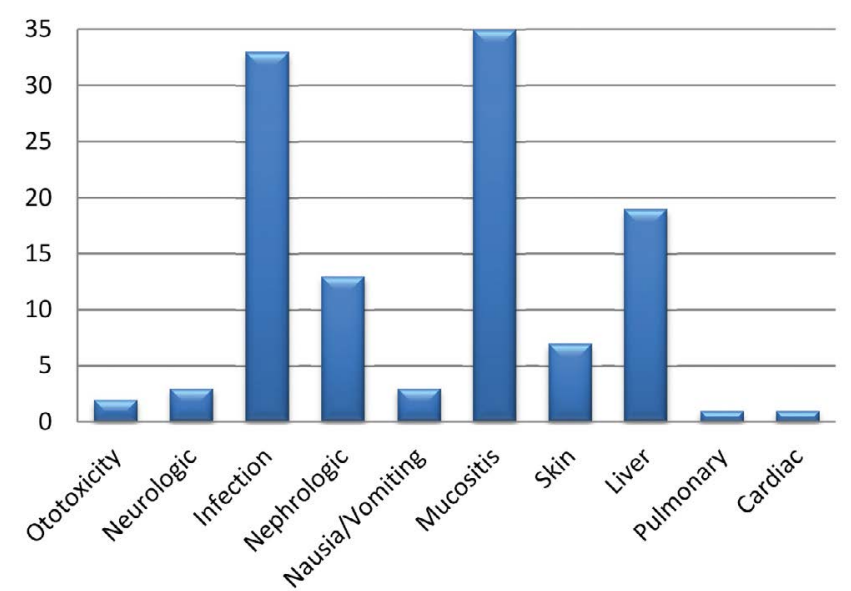

Figure 8. Distribution of Grade II-I toxicity according to organs and systems in CNS ATRT patients after HDCT/ auto-HSCT

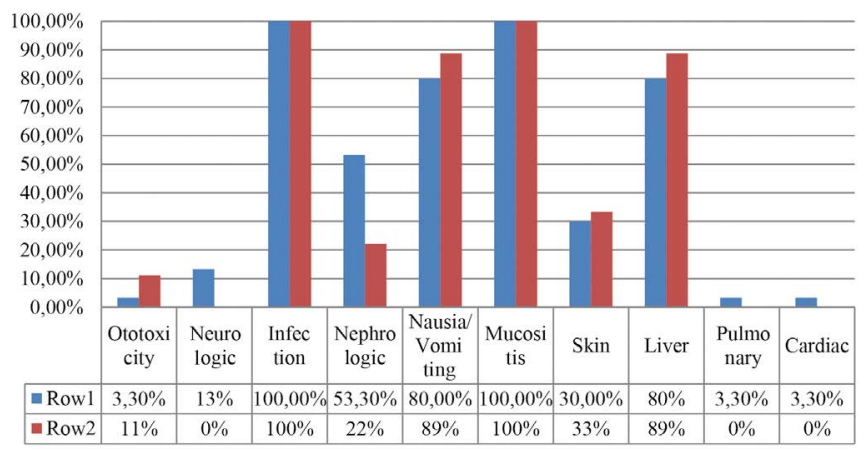

Figure 9. Comparative toxicity characteristics after single (blue bars) vs tandem (red bars) HDCT/auto-HSCT in CNS ATRT patients

\section{Discussion}

CNS ATRT is a rare malignancy with poor prognosis that is predominantly diagnosed in young children $[3,4]$. Nowadays there are no established standards for the treatment of CNS ATRT and prognosis remains dismal. It is generally accepted that in ATRT surgery should be followed by adjuvant chemotherapy with probable inclusion of RT depending on age $[7,8]$. HDCT/auto-HSCT may be used for the intensification of first line therapy with the intention to postpone RT in young children. Nowadays there is no consensus concerning the role of HDCT/auto-HSCT in the treatment of ATRT due to limited patient number, differences in conditioning regimens and $\mathrm{RT}$.

Initially HDCT/auto-HSCT was used by Hilden and coauthors in 2004 as part of therapy for CNS ATRT in 13 patients. Among 9 patients that received auto-HSCT 46\% remained alive and disease-free with total tumor resection in half and RT in only third [1]. According to data of Tekautz and coauthors [2] that were published in 2005 nine patients older than 3 years that were treated with craniospinal irradiation and HDCT demonstrated 2 -year OS of $89 \pm 11 \%$. In the Head Start II study 1-3 cycles of HDCT with carboplatin, thiotepa and etoposide were performed after induction therapy with high dose metotrexate (HD-MTX). It is worth mentioning that patients after HS I scheme (without HD-MTX) demonstrated inferior outcome compared to children with HDCT HS II (all 6 patients died of progression as opposed to 3 out of 7 alive and disease free patients). There was no RT in long term survivors [13]. Headstart III trial $(n=19)$ that included surgical resection of the tumor, 5 cycles of induction chemotherapy with HD-MTX and myeloablative HDCT/ auto-HSCT demonstrated 3-year OS and EFS of 26\% and $21 \%$, respectively [14]. It is important to mention that 5 cases of treatment related mortality (TRM) on induction therapy were registered.

Lafay-Cousin and coauthors observed higher OS rates in the patients after HDCT/auto-HSCT compared to standard chemotherapy alone (2-year OS $47.9 \pm 12.1 \%$ and $27.3 \pm 9.5 \%$, respectively) [15]. At the same time, it should be emphasized that among 9 survived patients after HDCT total tumor resection was performed in 55\% and $67 \%$ had localized disease at diagnosis. In the EU-RHAB study $(n=19)$ various 
conditioning regimens for tandem and single auto-HSCT were used. OS and EFS at 2 years were $50 \%$ and $29 \%$, respectively. There was no TRM [16]. In our study 12 patients treated according to EU-RHAB demonstrated OS and EFS of $40 \%$ and $32 \%$, respectively.

Fossey and coauthors showed improved 5-year OS in ATRT patients under 1 year of age after HDCT/auto-HSCT compared to infants without HDCT (52.0\% vs $10.7 \%$ respectively, $\mathrm{p}<0.001)$. Patients with CR prior to HDCT had significantly higher OS [17]. It underlines the importance of disease status prior to HDCT for prognosis and it is necessary to thoroughly select patients for HDCT.

It is worth of discussing the results obtained by Medical University of Vienna in CNS ATRT patients with M0-M3 stage (MUV). Treatment in post-surgery period included 3 blocks of 9-week chemotherapy with anthracyclines, alkylating agents, HD-MTX with addition of intrathecal chemotherapy (etoposide and cytarabine) and subsequent HDCT/autoHSCT. Local RT was postponed until the end of chemotherapy. This cohort of patients demonstrated $100 \%$ OS and $88.9 \pm 10.58 \%$ EFS at 5 years, thus being significantly higher as for the control group (OS $=56.3 \pm 11.3 \%$; EFS $=52.9 \pm 11 \%$ ) treated with various other approaches. According to data of these workers, chemotherapy was well tolerated, timing delays and dose reduction due to toxicity were minimal [18]. In our study, 11 patients treated according to MUV protocol showed 3-year OS and EFS of 70\% and 50\%, respectively. These results are higher than in patients treated by other protocols, however, without significant difference.

In a recent study by Yamasaky et al. [19], in a group of 34 CNS ATRT patients, 19 received HDCT/auto-HSCT with tandem $(n=13)$ transplantations in the majority of cases. Conditioning regimen consisted of thiotepa and melphalan. Two patients succumbed to sepsis in early post-transplant period. The study demonstrated better OS $(p=0.025)$ in CNS ATRT patients after HDCT/auto-HSCT compared to patients without HDCT. Protocol ACNS 0333 for the treatment of ATRT has been recently developed by the Children's Oncology Group (COG). It consists of induction chemotherapy combined with 3 cycles of HDCT/auto-HSCT and RT. The abovementioned study $(n=65)$ demonstrated 4-year EFS and OS of $48 \%$ and $57 \%$, respectively [9].

\section{Conclusion}

HDCT/auto-HSCT is an important treatment option for children with chemosensitive CNS ATRT. In our study, 5-year EFS and OS rates after transplantation were $44 \%$. The majority of relapses occurred during 24 months after diagnosis. These results are comparable to the majority of international studies. Survival of CNS ATRT patients after HDCT/auto-HSCT was significantly higher after total tumor resection, radiotherapy, intraventricular/intrathecal chemotherapy and complete response prior to auto-HSCT. Thus HDCT/auto-HSCT can postpone RT in younger children with CNS ATRT, but cannot substitute it. There was no statistical significant difference in survival between the patients following single and tandem transplantations. According to our data, HDCT/auto-HSCT demonstrated acceptable toxicity. Low incidence of CNS ATRT in children requires a large-scale multicentre randomized trials aiming for stratifying the patients into risk groups on the basis of clinical data, and clear indications for HDCT/auto-HSCT are crucial.

\section{Conflict of interest}

None reported.

\section{References}

1. Hilden JM, Meerbaum S, Burger P, Finlay J, Janss A, Scheithauer BW, Walter AW, Rorke LB, Biegel JA. Central nervous system atypical teratoid/rhabdoid tumor: results of therapy in children enrolled in a registry. J Clin Oncol. 2004; 22(14):2877-2884. doi: 10.1200/JCO.2004.07.073.

2. Tekautz T, Fuller C, Blaney S, Foulad M, Fouladi M, Broniscer A, Merchant TE, Krasin M, Dalton J, Hale G, Kun LE, et al. Atypical teratoid/rhabdoid tumors (ATRT): Improved survival in children 3 years of age and older with radiation therapy and high-dose alkylator-based chemotherapy. J Clin Oncol.2005;23(7):1491-1499. doi: 10.1200/JCO.2005.05.187.

3. Ostrom QT, Chen Y, de Blank P, Ondracek A, Farah P, Gittleman H, Wolinsky Y, Kruchko C, Cohen ML, Brat DJ, Barnholtz-Sloan JS. The descriptive epidemiology of atypical teratoid/rhabdoid tumors in the United States, 2001-2010. Neuro-Oncology. 2014; 16 (10): 1392-1399. doi: 10.1093/ neuonc/nou090.

4. Lau CS, Mahendraraj K, Chamberlain RS. Atypical teratoid rhabdoid tumors: a population-based clinical outcomes study involving 174 patients from the Surveillance, Epidemiology, and End Results database (1973-2010). Cancer Manag Res. 2015; 7: 301-309. doi: 10.2147/CMAR.S88561.

5. Zheludkova OG, Korshunov AG, Gorbatykh SV, Livshitz MI, Popov VE, Tarasova IS, Gorelyshex SK, Ozerova VI, Shcherbenko OI, Litvinov DV, Polushkina OB, Belogurova MB, Rusanova MG. Malignant theratoid-rhabdoid tumors of central nervous system in children. Voprosy Gematologii/ oncologii i Immunopathologii v Pediatrii. 2003; 2(3): 32-39 (In Russian).

6. Olkhova LV, Zheludkova OG, Kushel YuV, Melikyan AG, Gorelyshev SK, Ryzhova MV, Korshunov AG, Gorbatykh SV, Popov VE, Privalova LP, et al. Results of multidisciplinary study of atypical teratoid-rabdhoid CNS tumor treatment in children. Pediatriya. 2020; 99(4): 18-26 (In Russian). doi: 10.24110/0031-403X-2020-99-4-18-27.

7. Richardson EA, Ho B, Huang A. Atypical Teratoid Rhabdoid tumour: from tumours to therapies. J Korean Neurosurg Soc. 2018; 61(3): 302-311. doi: 10.3340/jkns.2018.0061.

8. Biswas A, Kashyap L, Kakkar A, Sarkar C, Julka PK. Atypical teratoid/rhabdoid tumors: challenges and search for solutions. Cancer Manag Res. 2016; 8:115-125. doi: 10.2147/ CMAR.S83472.

9. Reddy AT, Strother DR, Judkins AR, Burger PC, Pollack IF, Krailo MD, Buxton AB, Williams-Hughes C, Fouladi M, Mahajan A, et al. Efficacy of high-dose chemotherapy and three-dimensional conformal radiation for atypical teratoid/ 
rhabdoid tumor: a report from the Children's Oncology Group trial ACNS0333. J Clin Oncol. 2020; 38(11):11751185. doi: $10.1200 /$ JCO.19.01776.

10. Park M, Han JW, Hahn SM, Lee JA, Kim JY, Shin SH, Kim DS, Yoon HI, Hong KT, Choi JY et al. Atypical teratoid/ rhabdoid tumor of the central nervous system in children under the age of 3 years. Cancer Res Treat. 2020. Oct 28. doi: 10.4143/crt.2020.756. PMID: 33138347.

11. Yang WC, Yen HJ, Liang ML, Chen HH, Lee YY, Chang FC, Lin SC, Wong TT, Hu YW, Chen YW. Effect of early radiotherapy initiation and high-dose chemotherapy on the prognosis of pediatric atypical teratoid rhabdoid tumors in different age groups. J Neurooncol. 2020; 147 (3): 619-631. doi: 10.1007/s11060-020-03456-1.

12. Bartelheim K, Nemes K, Seeringer A, Kerl K, Buechner J, Boos J, Graf N, Dürken M, Gerss J, Hasselblatt M, et al. Improved 6-year overall survival in AT/RT - results of the registry study Rhabdoid 2007. Cancer Med. 2016; 5(8):17651775. doi: $10.1002 / \mathrm{cam} 4.741$.

13. Gardner SL, Asgharzadeh S, Green A, Horn B, McCowage $\mathrm{G}$, Finlay J. Intensive induction chemotherapy followed by high dose chemotherapy with autologous hematopoietic progenitor cell rescue in young children newly diagnosed with central nervous system atypical teratoid rhabdoid tumors. Pediatr Blood Cancer. 2008; 51(2):235-240. doi: 10.1002/ pbc. 21578 .

14. Zaky W, Dhall G, Ji L, Haley K, Allen J, Atlas M, Bertolone S, Cornelius A, Gardner S, Patel R et al. Intensive induction chemotherapy followed by myeloablative chemotherapy with autologous hematopoietic progenitor cell rescue for young children newly-diagnosed with central nervous system atypical teratoid/rhabdoid tumors: the Head Start III experience. Pediatr Blood Cancer. 2014; 61(1):95-101. doi: $\underline{10.1002 / \mathrm{pbc} .24648 .}$.

15. Lafay-Cousin L, Hawkins C, Carret AS, Johnston D, Zelcer S, Wilson B, Jabado N, Scheinemann K, Eisenstat D, Fryer $\mathrm{C}$, et al. Central nervous system atypical teratoid rhabdoid tumours: the Canadian Paediatric Brain Tumour Consortium experience. Eur J Cancer. 2012; 48(3):353-359. doi: 10.1016/j.ejca.2011.09.005.

16. Benesch M, Bartelheim K, Fleischhack G, Gruhn B, Schlegel PG, Witt O, Stachel KD, Hauch H, Urban C, Quehenberger F, et al. High-dose chemotherapy (HDCT) with auto-SCT in children with atypical teratoid/rhabdoid tumors (AT/RT): a report from the European Rhabdoid Registry (EU-RHAB). Bone Marrow Transplant. 2014; 49(3):370-375. doi: 10.1038/bmt.2013.208

17. Fossey M, Li H, Afzal S, Carret AS, Eisenstat DD, Fleming A, Hukin J, Hawkins C, Jabado N, Johnston D, et al. Atypical teratoid rhabdoid tumor in the first year of life: the Canadian ATRT registry experience and review of the literature. J Neurooncol. 2017; 132(1):155-162. doi: 10.1007/ s11060-016-2353-0.

18. Slavc I, Chocholous M, Leiss U, Haberler C, Peyrl A, Azizi AA, Dieckmann K, Woehrer A, Peters C, Widhalm G, Dorfer C, Czech T. Atypical teratoid rhabdoid tumor: improved long-term survival with an intensive multimodal therapy and delayed radiotherapy. The Medical University of Vienna Experience 1992-2012. Cancer Med. 2014 Feb;3(1):91-100. doi: 10.1002/cam4.161. Epub 2013 Dec 11. PMID: 24402832; PMCID: PMC3930393.

19. Yamasaki K, Kiyotani C, Terashima K, Watanabe Y, Kanamori M, Koga Y, Hata N, Iwasaki F, Goto H, Koh K, et al. Clinical characteristics, treatment, and survival outcome in pediatric patients with atypical teratoid/rhabdoid tumors: a retrospective study by the Japan Children's Cancer Group. J Neurosurg Pediatr. 2019 :1-10. doi: 10.3171/ 2019.9.PEDS19367. 


\title{
Высокодозная полихимиотерапия с аутологичной трансплантацией гемопоэтических стволовых клеток у детей с атипичной тератоид-рабдоидной опухолью центральной нервной системы
}

\author{
Людмила В. Ольхова ${ }^{1}$, Ольга Г. Желудкова ${ }^{2}$, Людмила С. Зубаровская ${ }^{3}$, Анна Ю. Смирнова ${ }^{4}$, Юлия В. Диникина ${ }^{4,5}$, \\ Асмик Г. Геворгян ${ }^{3}$, Андрей С. Левашов $^{6}$, Елена В. Скоробогатова ${ }^{1}$ \\ ${ }^{1}$ Обособленное структурное подразделение «Российская детская клиническая больница», Российский национальный \\ медицинский университет им. Н. И. Пирогова, Москва, Россия \\ ${ }^{2}$ Научно-практический центр специализированной медицинской помощи им. В. Ф. Войно-Ясенецкого, Москва, Россия \\ ${ }^{3}$ НИИ детской онкологии, гематологии и трансплантологии им. Р. М. Горбачевой, Первый Санкт-Петербургский \\ государственный медицинский университет им. акад. И. П. Павлова, Санкт-Петербург, Россия \\ ${ }^{4}$ Национальный медицинский исследовательский центр им. В. А. Алмазова, Санкт-Петербург, Россия \\ ${ }^{5}$ Санкт-Петербургский государственный педиатрический медицинский университет, Санкт-Петербург, Россия \\ ${ }^{6}$ Национальный медицинский исследовательский центр онкологии им. Н. Н. Блохина, Москва, Россия
}

\section{Резюме}

Атипичная тератоид-рабдоидная опухоль (АТРО) центральной нервной системы (ЦНС) - это агрессивная злокачественная опухоль, встречается преимущественно у детей младшего возраста и характеризуется плохим прогнозом. В настоящее время нет единых стандартов лечения АТРО ЦНС. Данное ретроспективное исследование выполнено с целью оценки результатов высокодозной полихимиотерапии (ВДХТ) с последующей аутологичной трансплантацией гемопоэтических стволовых клеток (ауто-ТГСК) у детей с АТРО ЦНС и определения влияния различных факторов прогноза на выживаемость. В исследование включены 30 больных с АТРО ЦНС, которые в протоколе терапии получали ВДХТ с ауто-ТГСК. Медиана возраста пациентов составила 19,5 месяцев [9; 27]. Распределение пациентов в зависимости от возраста было следующим: младше 12 месяцев - 11 (36,6\%), старше 12 месяцев $19(63,4 \%)$; по полу: мальчиков - $21(70 \%)$ и девочек 9 (30\%). Опухоль у 17 пациентов (56,7\%) локализовалась инфратенториально, у 13 (43,3\%) - супратенториально. Всем пациентам инициально выполнено хирургическое лечение в различных объемах: тотальное удаление опухоли - у 8 (26,7\%) пациентов, субтотальное - у 9 (30,0\%), частичное удаление у $11(36,6 \%)$, биопсия - у 2 (6,7\%). В анализируемой группе преобладали больные с $\mathrm{M}+$ стадией заболевания - 16 пациентов (53,3\%), у 12 (40,0\%) метастазирование и опухолевые клетки отсутствовали, установлена М0-стадия, у 2 (6,7\%) - стадия заболевания не уточнена (Mx). Все пациенты после удаления опухоли получали лечение по различным протоколам терапии: 12 пациентов (40,0\%) - по протоколу
EU-RHAB, 11 (36,7\%) - по протоколу MUV-ATRT, y 7 (23,3\%) больных выполняли индивидуальные схемы. ЛТ проведена 24 больным (80\%) после ВДХТ с ауто-ТГСК. Интратекальное/интравентрикулярное введение химиопрепаратов получили большинство пациентов ( $\mathrm{n}=22,73,3 \%)$. Статус заболевания оценивался у всех пациентов до выполнения ВДХТ с аутоТГСК: полный ответ (ПО) был зарегистрирован у 12 пациентов (40\%), стабилизация болезни (СБ) у $10(33,3 \%)$, частичный ответ (ЧО) - у 8 (26,7\%). Большинству пациентов выполнена однократная ауто-ТГСК - 21 (70\%), тандемная ауто-ТГСК - у 9 (30\%) пациентов. Общее количество выполненных ауто-ТГСК у пациентов с АТРО ЦНС составило 39. В качестве источника трансплантата в 90\% ( $\mathrm{n}=27)$ были использованы СКПК, у 10\% (n=3) больных использовали комбинацию СКПК+КМ. Результаты: 5 -летняя БСВ и ОВ составили $44 \%$, большинство рецидивов диагностировано в течение 24 месяцев после постановки диагноза. Эти результаты сопоставимы с большинством международных данных. Выживаемость пациентов с АТРО ЦНС, получивших ВДХТ с ауто-ТГСК, статистически достоверно выше была при выполнении тотальной резекции опухоли, проведении ЛТ и регионарной химиотерапии и достижении ПО к моменту проведения ТГСК.

\section{Ключевые слова}

Дети, младший возраст, атипичная тератоид-рабдоидная опухоль, центральная нервная система, химиотерапия, высокодозная, лучевая терапия, результаты лечения, выживаемость, прогностические факторы. 